\section{Visión Electrónica Más que un estado sólido \\ https://doi.org/10.14483/issn.2248-4728}

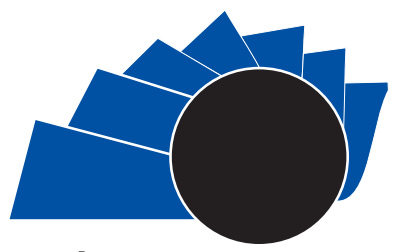

VISIÓN ELECTRONICA

UNIVERSIDAD DISTRITAL

FRANCISCO JOSÉ DE CALDAS

A Case-Study Vision

\title{
Automation of the mechanical tensile and three-point flexural test
}

\author{
Automatización de ensayos mecánicos de tracción y flexión por tres puntos \\ Zaida Margelly Hernández-Gómez , Edgar Mauricio Castillo-Robles², \\ Diego Andrés Campo-Ceballos ${ }^{3}$
}

\section{INFORMACIÓN DEL ARTICULO}

Historia del articulo

Enviado: 20/09/2018

Recibido: 03/10/2018

Aceptado: 18/10/2018

\section{Keywords:}

ASTM,

HMI-PLC,

Tensile,

Three-point flexural test, Universal testing machine design.

\footnotetext{
Palabras clave:

ASTM,

HMI-PLC,

Tensión,

Prueba de flexión de tres puntos, Diseño Máquina universal de ensayos.
}

\begin{abstract}
This paper presents the design and implementation of Mechanical system testing for tensile and three-point flexural test for both metallic and polymeric materials. A control and monitoring system was adapted to the data, using specialized equipment for industrial automation, i.e. PLC system. Main Parameters to perform the tensile and three point flexural tests, and the functional and technical specifications according to the ASTM (American Society of Testing Materials) standards were defined. Conceptual design, mathematical calculations and CAD designs were developed using Solidworks. Graphical user interfaces (GUI) were designed to interact with the user. Human machine interface (HMI) was implemented in proprietary software and includes rules for the supervision and manipulation of core variables for the user according to the ASTM standard. The HMI was interconnected with a programmable logic controller (PLC) where the process selection rules was implemented in GRAFCET diagram, following the ASTM protocols. The system has a test capacity of $500 \mathrm{Kgf}$ both for the tensile test and for the three-point flexural test, with an accuracy of $\pm 2 \%$, under the ASTM E177 standard, and the HMI interface as an innovative monitoring and control system.
\end{abstract}

\section{RESUMEN:}

En este trabajo se presenta el diseño e implementación de un banco de pruebas de un sistema para ensayos mecánicos de tracción y flexión por tres puntos para materiales metálicos y plásticos, adaptando un sistema de control y monitoreo de los datos utilizando equipo especializado para automatización. Se definieron parámetros para realizar los ensayos de tracción y flexión, y las especificaciones funcionales y técnicas que debe poseer la máquina según las normas ASTM (American Society of Testing Materials). Se desarrolló el diseño conceptual, los cálculos matemáticos y diseños en CAD usando Solidworks. Se diseñaron las interfaces gráficas de usuario (Graphical User Interface, GUI) para interactuar con el operador. La interfaz hombre-máquina (Human Machine Interface, HMI) se implementó en software propietario y contempla reglas para supervisión y manipulación de las variables del sistema para el operador según la norma ASTM. La HMI se interconectó con un controlador lógico programable (PLC) donde se implementaron las reglas de selección del proceso en diagrama grafcet, mediante el protocolo de ensayo. Se obtuvo que el sistema tiene una capacidad ensayo de $500 \mathrm{Kgf}$, tanto para el ensayo de tracción como para el ensayo de flexión, con una precisión de $\pm 2 \%$, bajo la norma ASTM E177, y una interfaz HMI como sistema de control y supervisión novedosa.

\footnotetext{
'BSc. In Electronic Technology, Eng. In Mechatronics, Corporación Universitaria Comfacauca - Unicomfacauca, Colombia. Current position: Mechatronics research incubator program. E-mail:zmhg16@hotmail.com. ORCID: https://orcid.org/0000-0002-7295-9582

${ }^{2}$ BSc. In Electronic Technology, Eng. In Mechatronics, Corporación Universitaria Comfacauca- Unicomfacauca, Colombia. Current position: Mechatronics research incubator program. E-mail: maurocast84@hotmail.com. ORCID: https://orcid.org/0000-0001-5245-3683

3 BSc. In Physics Engineering, Universidad del Cauca, Colombia. MSc. In Mechatronics Systems. Universidad de Brasilia, Brasil. PhD. Student in Electronics Sciences, Universidad del Cauca, Colombia. Current position: Professor at Corporación Universitaria Comfacauca- Unicomfacauca, Colombia; Research Group in Intelligent System. E-mail: dcampo@unicomfacauca.edu.co. ORCID: https://orcid.org/0000-0001-7458-5820

Cite this article as: Z. M. Hernández-Gómez, E. M. Castillo-Robles and D. A. Campo-Ceballos, "Automation of the mechanical tensile and three-point flexural test", Visión electrónica, algo más que un estado sólido, vol. 1, no. 2, Special edition, july-december 2018, DOI revista: https://doi.org/10.14483/issn.2248-4728
} 


\section{Introduction}

The small-scale mechanical testing systems at Corporación Universitaria Comfacauca, Unicomfacauca, Popayán, enable customized test methods to investigate metals, ceramics, and polymers specimens. Mechatronics Engineering program studies materials science of engineering and resistance devices, which require of a small-scale machine of mechanical tests that allow to realize practices of laboratory in the engineering materials, providing a complete automatic report of the mechanical properties of the material according to the ASTM standards, and to provide the critical information that will directly enable in the mechanical behavior of materials, to propose a novel form for the automatic analysis of mechanical tensile and three-point flexural test. Traditionally, among other tests, consist of measuring tensile and bending stress in different types of materials, however, it is very important to provide a system that automatically performs its respective correlation with quality indicators of the testing materials. Main data was obtained of the strain and stress, predicting defects, failures and analyses in a destructive test. In machine design process, different factors were considered such as the type of test, the type of material and the size of the specimens for grip accessories design. On the other hand, industrial instrumentation and data acquisition to control and monitoring the force application was implemented. The measurement of the load and the displacement and the data collection, was obtained automatically, through a programmable logic controller and a HMI-PLC user interface. The conceptual design was based on the mathematical calculations of both the maximum stresses allowed for the machine and the work area in ASTM standards, [1], [2]. The function of the small-scale testing machine is focused on performing tensile and three-point flexural tests in different materials, with the ASTM E8M [3], ASTM E290 [4], ASTM D638 [5], and ASTM D790 [6] standards for an automatic report of the mechanical behavior of engineering materials. Tensile and bending tests involve a number of variables which can significantly affect their results and need to be considered particularly carefully when they are used to determine the mechanical properties of fibre-plastics and metallic materials [7-9]. Test variables has been critically examined therefore, with both manual or automatic modes of supporting specimens in tensile and three-point bending in particular mechanical machines, a comparison of the results obtained leads to explore HMI interface as an innovative monitoring and control system for data analysis [10-13]. In this paper the development of an automatic testing machine for plastic and metallic material is presented. The work is undertaken considering the high cost of the presently available universal testing machines. The proposed machine is a new in design and economical. The machine is equipped with speed measurement, speed control, force measurement, displacement measurement and HMI interface and data acquisition system.

For the validation of the machine, tensile and threepoint flexural testing of some samples is carried out and the results are presented to show the efficiency of the system. The results show that the machine is capable of satisfying the requirements of ASTM standard.

\section{Materials and methods}

Taking into account a linear sequential model, the following phases for the designed mechanical testing machine were adopted:

- Identification of the need: Generate a report of a mechanical tensile and bending test according to ASTM standards, with adequate precision.

- Definition of the design requirements of the machine according to the characteristics: the maximum load applied in the samples is taken into account, according to the ASTM E8M [3], ASTM E290 [4], ASTM D638 [5], and ASTM standards. D790 [6], specifying the use of rectangular standard specimens, with mechanical clamps as grip system in the tensile test, and simple support in 3 points with central load for the bending test, double column structure which has 3 plates, the transmission of force made by two endless screws.

- Mathematical analysis of the plates of the structure: Design and simulation of columns, mechanical supports and power screws.

- Definition of the instrumentation. Force measurement system, $1000 \mathrm{Kg}$ span S type load cell. Displacement measurement system with an incremental type encoder.

- Manual control system: Control panel with push buttons, and emergency stop.

- Automatic control system: Industrial instrumentation from PLC to HMI system.

- Control system: PLC and operated from the HMI screen, which also graphs the data obtained in real time in each test.

- Force generation system. Mechanical system, threephase gear motor with a power of $1 \mathrm{Hp}$, three gear wheels, and transmission chain, which generates 
the necessary force which will be transmitted by the endless screws.

-Evaluation of the tests: Systematic validation of the mechanical properties of the metallic and polymeric materials. Comparative method or mechanical behavior of the material.

\section{Results and discussion}

The universal testing machine was implemented taking into account both, functional and structural systems, accessories for testing, measurement system and the power generation system was conducted by mechatronics systems design.

\subsection{Protocol for mechanical testing}

The protocol is presented in Figure 1.

As an initial result, a protocol for mounting the test specimens was established. To start tensile or threepoint flexural tests, the material to be tested is chosen, the test speed is adjusted according to the ASTM criteria, which is executed by the speed controller controlled by a PLC, the test piece is located in the jaws, for the case of the tensile test, or in the three-point accessory, for the bending test, and the start command is given from the HMI screen, collecting the data from the load cell and the encoder in time real to obtain the graph of the corresponding test. The tests end when the load cell no longer exerts force on the specimen and compare graphically and analytically the theoretical values with the experimental values.

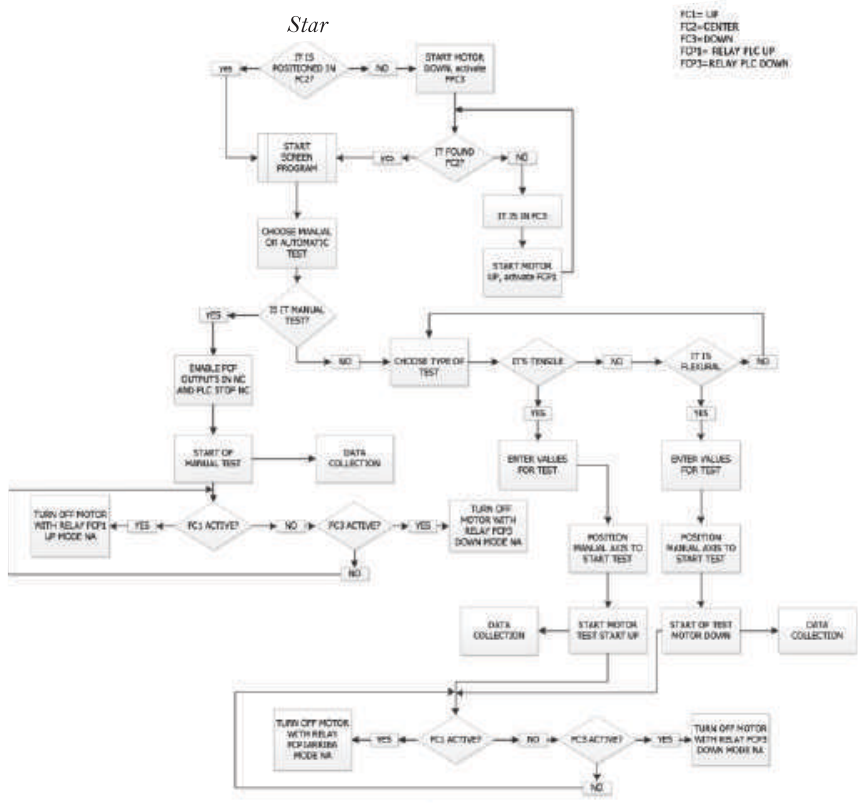

Figure 1. Protocol for mechanical testing system. Source: own.

\subsection{Mechanical system}

Mechanical system was obtained following the main variables of ASTM criteria and structure. Mathematical results are shown as well as the design considerations in Table 1.

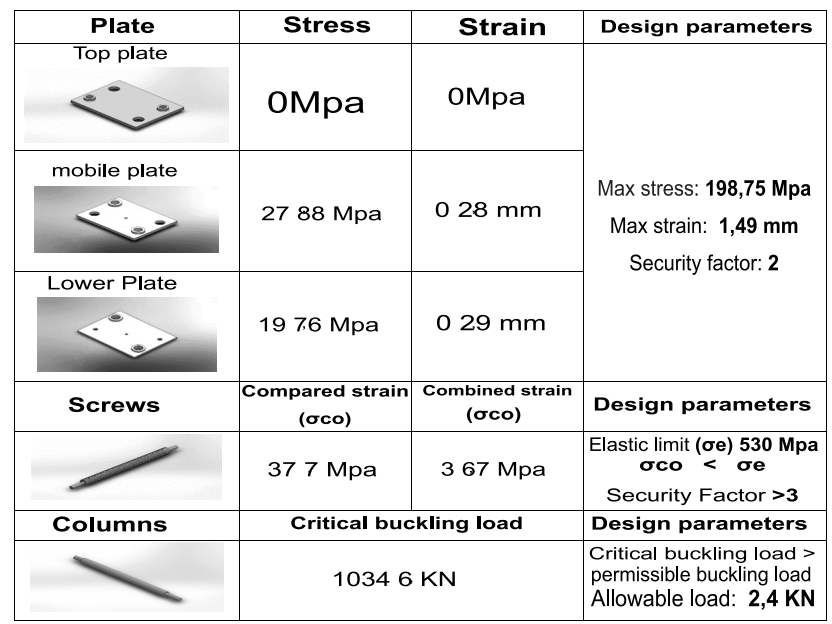

Table 1. Structural parameters of the proposed universal testing machine. Source: own.

- Fixed lower plate: Base for the structure and as an accessory fix ture for tests.

- Fixed top plate: Which serves as balance and support of the screws and columns to prevent the buckling of these elements.

- Mobile plate: on it is located the instrument of force measurement, as well as the accessories of subject of test pieces, besides that is the one that exerts the force transmitted by the endless screws.

- Two endless screws, used to transmit the force applied from the reduction motor.

- Two columns for support and guide of the structure.

\subsection{Electronic system}

The circuit is composed of a $12 \mathrm{~V}$ dual voltage source to power the operational amplifiers. A voltage source of $10 \mathrm{~V}$ for power supply to the load cell. The signal conditioning for the electrical signal and the amplification of the signal emitted by the S-type load cell, was implemented. The main variables for government the electronics systems were describe as following. Application tension or compression. Maximum capacity $1 \mathrm{~T}=1000 \mathrm{Kgf}=9.8 \mathrm{KN}$ and sensitivity $2,0+-0,2 \% \mathrm{mV} / \mathrm{V}$. Maximum capacity proposed 500Kgf

Load cell power stabilized systems: 


$$
\begin{array}{ll}
0 \mathrm{kN} & \rightarrow \mathrm{V}=0 \mathrm{mV} * 500 \mathrm{kgf}=0 \mathrm{~V} \\
10 \mathrm{kN} & \rightarrow \mathrm{V}=20 \mathrm{mV} * 500 \mathrm{kgf}=10 \mathrm{~V}
\end{array}
$$

To obtain the gain of 500 times the value delivered by the load cell, an analogic to digital IC (AD620) was integrated and the mathematical model for gain and the resistance calculations is presented in equation 2:

$\mathrm{G}=1+\frac{49.4 \mathrm{k} \Omega}{R_{0}}$ where, $R_{0}=\frac{49.4 \mathrm{k} \Omega}{\mathrm{G}-1}=\frac{49.4 \mathrm{k} \Omega}{500-1}=99.2 \Omega \cong 100 \Omega$

Where $G$ is the gain and Ro the value of the resistance for the AD system. The signal conditioning circuit of the load cell was designed. in Figure 2, double-sided printed circuit design shows the components of the circuit: AO AD620, AO TL081, transformer, rectifier, electrolytic capacitors 2200uFf, 220uF, 330uF, 10uF, $22 \mathrm{uF}$, ceramic capacitors $100 \mathrm{nF}$, voltage regulators 7812, 7912, LM317, precision potentiometers of $5 \mathrm{~K}$, $100 \mathrm{~K}$, resistors of $100 \mathrm{ohm}, 240 \mathrm{ohm}, 1 \mathrm{~K}, 1.5 \mathrm{~K}$ and $1 \mathrm{~N} 4002$ diodes.
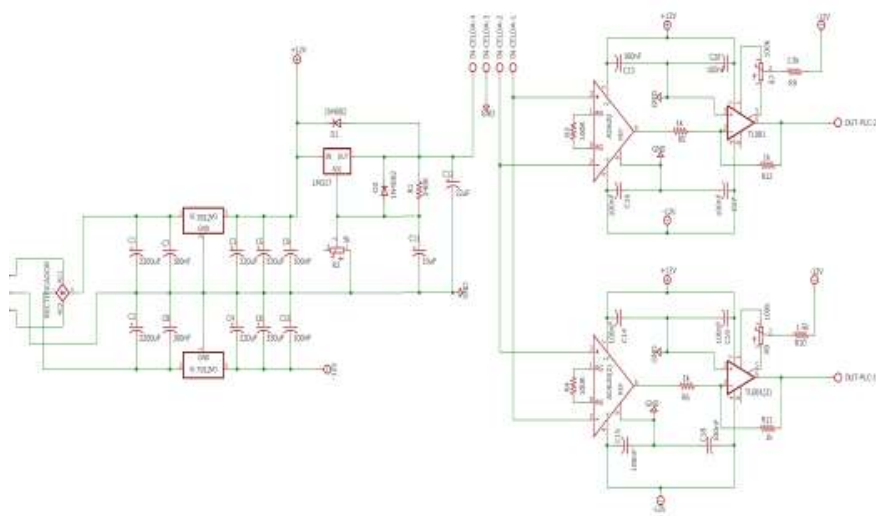

Figure 2. Electronic design for mechanical testing machine system. Source: own.

\subsection{Control system}

For the control system, the GRAFCET diagram was designed. GRAFCET (GRAphe Fonctionnel de Commande Etapes/Transitions) or Step Transition function chart, is a standard which may be used to describe a control function or a machine. In order to implement it in the small-scale machine testing and validate its operation, GRAFCET helps to guarantee the best possible, highly efficient working relationships. The system operator is better able to understand the machine's processes using the GRAFCET and maintenance staff can remedy disruptions faster as the system's functions can gauge faster.

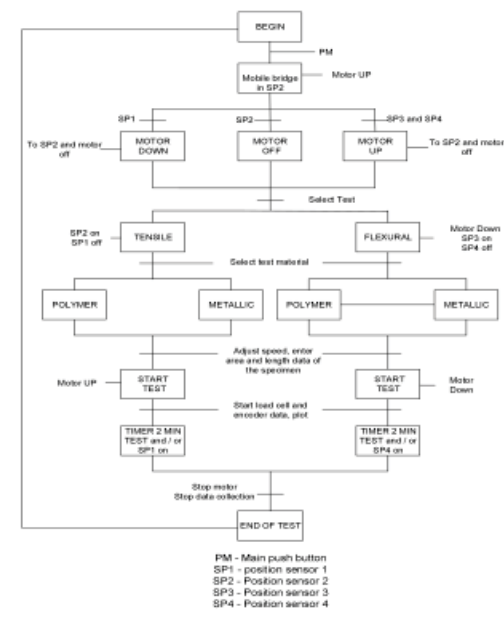

Figure 3. GRAFCET for the small-scale machine testing control system. Source: own.

The first test validates the experimental test data, adjusts them and generates a report of the mechanical behavior and properties of the tested material in both tensile and three-point flexural (bending).

\section{Conclusion}

The design of small-scale machine testing has high safety factors and allows the application of controlled loads from $0 \mathrm{~kg}$ to $500 \mathrm{kgf}$. The capacity of this applied force allowed to the prototype to perform the required number of tests according to the ASTM standard, presenting the automatic reports that interpret the mechanical properties of the material in tension or three- point flexural test. Industrial instrumentation embedded in the system, guaranteed a reliable operation of the machine, with a degree of accuracy of $\pm 2 \%$, for $0-850 \mathrm{MPa}$ strain span. Simulation step of a tensile test properly showed the deployment and integration of a global mechanical test report (Template), which allowed to give way to a greater abstraction of the mechanical properties of both metallic and polymeric materials, in terms of data analysis Experimental supported by the descriptive statistics performed automatically. To complete the validation of the experimental data, both manual and automatic control systems must be integrated, following the ASTM standards for monitoring and data acquisition system by comparing the mechanical properties such as the module of elasticity with ISO and ASTM standards. Elasticity modulus from tensile and three-point flexural test of materials such as PET and aluminum, were tested with precision of $5 \%$.

\section{Acknowledgements}

This research was supported by Research Group in Intelligent Systems, Corporación Universitaria Comfacauca, Popayán, Cauca, Colombia. We thank our colleagues from Brasilia University, UnB, who supporting final tests. 


\section{References}

[1] ASTM International, "ASTM

International”, 2017. [Online]. Available at: www.astm.org.

[2] ASTM, "Standard Practice for Use of the Terms Precision and Bias in ASTM Test Methods", 2016. [Online]. Available at: https://www.astm.org/Standards/E177.h $\underline{\mathrm{tm}}$.

[3] ASTM, "Standard test methods for tensile testing of metallic materials", 2004. [ O n l in e ]. Ava il a ble a t: https://www.astm.org/DATABASE.CAR T/HISTORICAL/E8E8M-13.htm.

[4] ASTM, "Standard Test Methods for Bend Testing of Material for Ductility", 1998. [Online ]. Avail a ble a t: https://www.astm.org/Standards/E290.h $\underline{\mathrm{tm}}$.

[5] ASTM, "Standard Test Method for Tensile Properties of Plastics", 2004. [Online]. A va i l a ble a t : https://www.astm.org/Standards/D638.

[6] ASTM, "Standard Test Method for Flexural Properties of Unreinforced and Reinforced Plastics and Electrical Insulation Materials", 2015. [Online]. A v a i l a ble a t : https://www.astm.org/Standards/D790. $\underline{\mathrm{htm}}$.

[7] F. Mujika, A. Valea, P. Gañan and I. Mondragon, "Off-axis Flexure test: a new method for obtaining in-plane shear properties", Journal of Composite Materials, vol. 39, no. 11, 2005, pp. 953-980. https://doi.org/10.1177\%2F0021998305 $\underline{048735}$.

[8] M. Abo-Elkher, A. Hamada and A. Bahei, "Prediction of fatigue life of glass fiber reinforced polyester composites using modal testing", International Journal of
Fatigue, vol. 69, 2014, pp. 28-35. https://doi.org/10.1016/j.ijfatigue.2012.1 $\underline{0.002}$.

[9] G. Vargas and F. Mujika, "Determination of In-plane Shear Strength of Unidirectional Composite Materials Using the Off-axis Three-point Flexure and Offaxis Tensile Tests", Journal of Composite Materials, vol. 44, no. 21, 2010, pp. 2487$\begin{array}{llll}2 & 5 & 0 & 7\end{array}$ https://doi.org/10.1177/0021998310369 $\underline{601 .}$

[10] P. Kulkarni, P. Sawant and V. Kulkarni, "Design and Development of Plane Bending Fatigue Testing Machine for Composite Material”, Materials Today: Proceedings, vol. 5, no. 5, 2018 , pp. $\begin{array}{llllllllllll}1 & 1 & 5 & 6 & 3 & - & 1 & 1 & 5 & 6 & 8\end{array}$. https://doi.org/10.1016/j.matpr.2018.02. $\underline{124}$.

[11] A. Liu and S. CY Lu, "A New Coevolution Process for Conceptual Design”, CIRP Annals, vol. 64, no. 1, 2015, pp. 153-156. https://doi.org/10.1016/j.cir p.2015.04.02 $\underline{0}$.

[12] Y.H. Yin, A. Nee, S. Ong, J. Zhu, P. Gu and L. Chen, "Automating design with intelligent human-machine integration", CIRP Annals, vol. 64, no. 2, 2015, pp. 655-677. https://doi.org/10.1016/j.cirp.2015.05.00 $\underline{8}$.

[13] M.-P. Pacaux-Lemoin, D. Trentesaux, G. Zambrano and P. Millota, "Designing intelligent manufacturing systems through Human-Machine. Cooperation principles: A human-centered approach", Computers $\mathbb{E}^{\circ}$ Industrial Engineering, vol. 111, 2017, pp. 581-595. 